\title{
Filtration capacity of the ascidian Ciona intestinalis and its grazing impact in a shallow fjord
}

\author{
J. Kjerulf Petersen ${ }^{1}$, H. U. Riisgård ${ }^{2}$ \\ ${ }^{1}$ National Environmental Research Institute, Frederiksborgvej 399, PO Box 358, DK-4000 Roskilde, Denmark \\ ${ }^{2}$ Institute of Biology, Odense University, Campusvej 55, DK-5230 Odense M, Denmark
}

\begin{abstract}
Filtration capacity of the ascidian Ciona intestinalis (L.) was measured in the laboratory and determined from the exponential reduction in algal cell (Rhodomonas sp.) concentration as a function of time. Filtration rate $\left(F, \mathrm{ml} \mathrm{min}^{-1}\right)$ as a function of dry weight $(W, \mathrm{~g})$ was found to be $F=118 W_{\text {total }}^{0.68}$ and $F=199 W_{\text {organ }}^{0.67}$ for total dry weight and dry weight of organs, respectively. Ascidians starved at least $12 \mathrm{~h}$ had, after addition of algal cells, an initial lag-phase ( 1 to $2 \mathrm{~h}$ ) with low filtration rates before constant high rates were attained. The duration of the initial lag-phase was longer at low algal cell concentrations. At algal cell concentrations above 10 to $15 \times 10^{3}$ cells ml ${ }^{-1}$, the filtration rate declined to a lower level after some time, possibly correlated with the filling of the gut. In the temperature range 4 to $21^{\circ} \mathrm{C}$, maximum filtration rate $\left(F_{\mathrm{max},} \mathrm{ml} \mathrm{min}^{-1}\right.$ ind. $\left.^{-1}\right)$ increased linearly with increasing temperature $\left(T,{ }^{\circ} \mathrm{C}\right)$ according to $F_{\text {max }}=1.46 T-1.21$. Above $21{ }^{\circ} \mathrm{C}$ filtration rate declined rapidly with increasing temperature. The population density of $C$. intestinalis in the shallow cove Kertinge Nor, Fyn, Denmark, was estimated using analysis of stereophotographs. Population density varied greatly over the year with maximum densities in autumn. The filtration potential of the $C$. intestinalis population varied during the year between 0.1 and 1.0 times a volume equivalent to the total water volume of the cove per day. The results suggest that the population of $C$. intestinalis in Kertinge Nor may have an important grazing impact on the phytoplankton in late summer-early fall.
\end{abstract}

\section{INTRODUCTION}

Ciona intestinalis (L.) f. typica is a euryhaline phlebobranchiate ascidian with an annual life cycle and worldwide distribution (Dybern 1965). It is epibenthic with no specific substrate preferences, but is especially abundant on rocky substrates and subtidal rock walls (Dybern 1965), on eelgrass and macroalgae (Dybern 1963) and in fouling communities. In spite of reported high densities (>5000 $\mathrm{m}^{-2}$; Millar 1971) the importance of $C$. intestinalis and other ascidian species in the flow of energy and nutrients is poorly understood. High population densities and an efficient filtration mechanism suggest that this species may have a significant influence on primary production and concentration of suspended organic particles.

Ascidians feed by pumping the surrounding water through a continuously produced mucus net, in which the suspended particles are trapped, and the net is subsequently swallowed (Millar 1971). It is well estab- lished that the mucus net of Ciona intestinalis completely retains particles down to a size of about 1 to $2 \mu \mathrm{m}$ (Randløv \& Riisgård 1979, Jørgensen et al. 1984), but the reported filtration rates vary greatly among studies (Fiala-Médioni 1978a, b, Randløv \& Riisgård 1979, Robbins 1983).

Filtration rates in filter feeders are dependent on external factors such as temperature and ambient particulate concentration. Several workers have dealt with effects of temperature on filtration rate in filterfeeding bivalves (Jørgensen et al. 1990) and have found low filtration rates at low temperatures. The reason why reduced filtration rates occur at low temperatures is, however, not clear. In recent studies of the effects of temperature on the ciliary pump of the blue mussel Mytilus edulis (Jørgensen et al. 1990) and the polychaete Sabella penicillus (Riisgård \& Ivarsson 1990 ) it was found that filtration rate increased linearly with temperature and that most of the temperature effect could be ascribed to changed viscosity of sea- 
water An inverse relationship between particle concentration and filtration rate has been reported for both mussels (Winter 1973, Navarro \& Winter 1982) and ascidians (Fiala-Médioni 1979, Robbins 1983) and has been interpreted as a regulatory mechanism for controlling filtration rate above a certain high algal concentration and for keeping cell intake constant. It is, however, uncertain whether reduced filtration rates at high particulate concentrations are due to 'suboptimal conditions' (Jørgensen et al. 1988), a protective reaction against overloading of the digestive system (Riisgård \& Møhlenberg 1979, Riisgård 1991), or a regulatory mechanism (Navarro \& Winter 1982).

The aim of the present work was to study the filtration capacity of Ciona intestinalis and, in particular, to establish the potential grazing impact of this species in the inner part of a Danish fjord where it is found in large numbers.

\section{MATERIALS AND METHODS}

Ciona intestinalis were collected from leaves of eelgrass Zostera marina at 2 to $3 \mathrm{~m}$ water depth in Kertinge Nor on the east coast of the island of Fyn, Denmark (Fig. 1), during March-April 1991. The ascidians were taken to the nearby Fjord Biological Laboratory, Kerteminde, and kept at ambient temperature $\left(5\right.$ to $15^{\circ} \mathrm{C}$ ) and salinity ( 15 to $18 \%$ ) before they were used for experiments either at the laboratory or at the National Environmental Research Institute (NERI). The ascidians were transported to NERI by car in insulated seawater boxes, and then transferred to aquaria containing seawater with the same salinity and temperature as at the collection site. The seawater in the aerated holding aquaria was changed 1 to 3 times a week and fresh seawater was used in all experiments. The animals were fed daily with algal cells (Rhodomonas sp.).

Filtration rate. Filtration rate, defined as clearance of $100 \%$ efficiently retained particles (= pumping rate). was measured as the volume of water cleared of almost spherical flagellate cells [Rhodomonas sp.; equivalent spherical diameter $(E S D)=c a 6 \mu \mathrm{m}$ (range 4.8 to $8 \mu \mathrm{m})$ ] per unit time. Algae were added to a known volume of water $(V)$ in an aerated glass beaker with one or more ascidians (see below). The size of the glass beaker was dependent upon the size and number of ascidians and varied from $150 \mathrm{ml}$ to $3 \mathrm{l}$. The reduction in the number of algal cells as a function of time was followed by taking water samples and subsequently measuring the concentration of algal cells between 4.8 and $8 \mu \mathrm{m}$ with an Elzone 180 electronic particle counter equipped with a

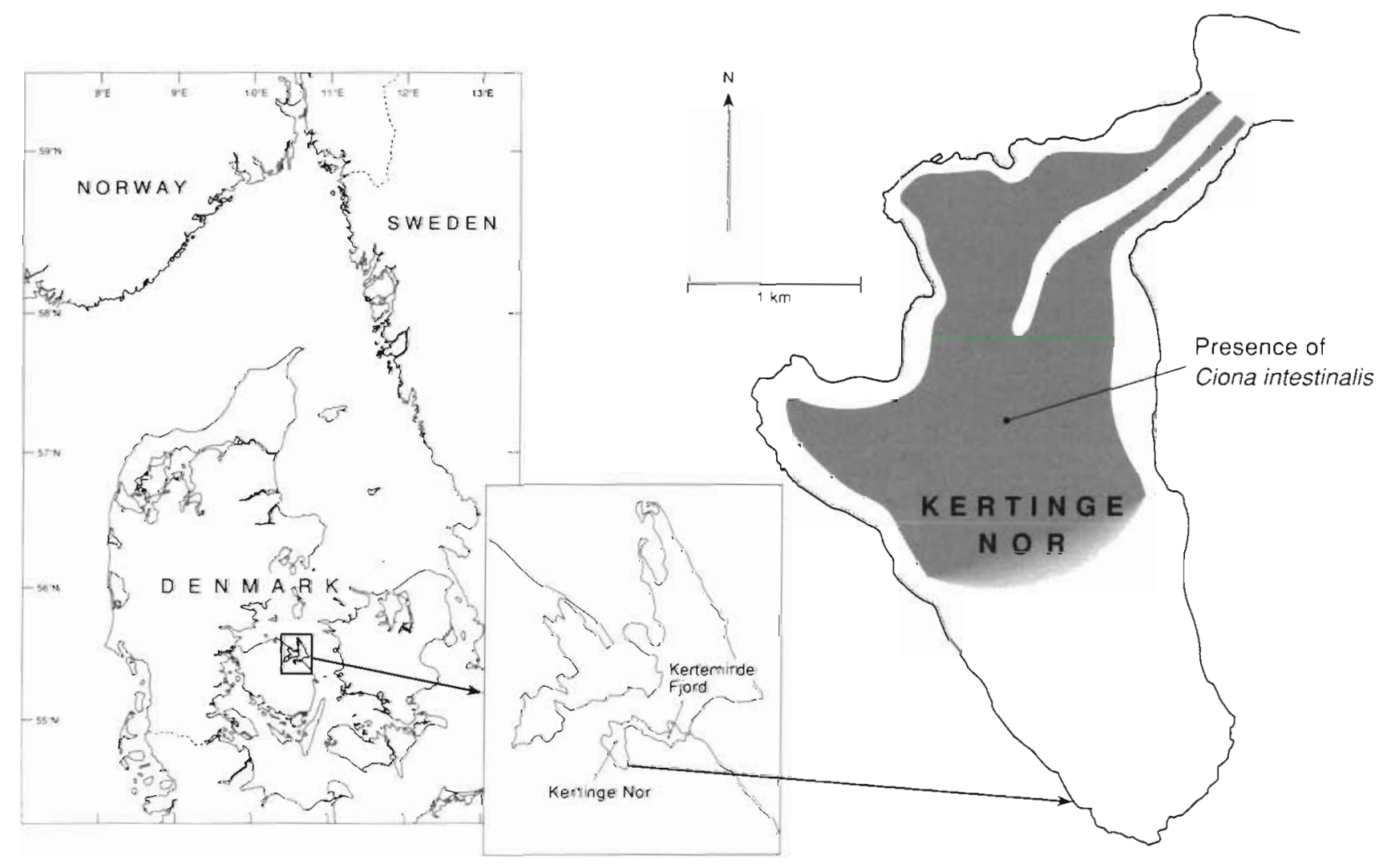

Fig 1. Investigation area. Shaded area indicates extend of the Ciona intestinalis population 
$64 \mu \mathrm{m}$ orifice tube. Filtration rate $(F)$ was determined from the exponential reduction in algal cell concentration as a function of time (always verified as a straight line in a semi-log plot made by hand during the experiment) following Randløv \& Risgård (1979), and using the formula: $F=[V /(t \times n)] \ln \left(C_{0} / C_{t}\right)$ where $C_{0}$ and $C_{t}$ are algal cell concentrations at times 0 and $t$ respectively and $n$ is the number of ascidians.

Ascidians used for filtration experiments were kept in the experimental beaker for at least $14 \mathrm{~h}$ before the experiments were started. Only stable filtration rates, abtained some time after the first addition of algal cells, were used. No significant change ( $\pm 5 \%$ ) in algal cell concentration in the controls (i.e. glass beakers with no ascidians) was seen during $100 \mathrm{~min}$.

Algal cell concentration. Filtration rates were measured at 6 algal cell concentrations - 2, 5, 10, 15, 20 and $30 \times 10^{3}$ cells $\mathrm{ml}^{-1}-$ for at least $300 \mathrm{~min}$ at each concentration on a group of 'small' [range: 7 to $20 \mathrm{mg}$ total dry weight $\left(W_{\text {total }}\right), \mathrm{n}=10$ ) and a group of 'large' (range: 100 to $240 \mathrm{mg} W_{\text {total }} \mathrm{n}=6$ ) Ciona intestinalis, kept in 2 beakers of 1.8 and $3.5 \mathrm{l}$, respectively, at $15^{\circ} \mathrm{C}$ (range: 15.0 to $15.8{ }^{\circ} \mathrm{C}$ ) and $16 \%$ salinity. The ascidians were not fed for at least $12 \mathrm{~h}$ prior to an experiment.

Temperature effect. The filtrations rate of 4 individuals and 2 groups ( $n=6$ in each group; range: 40 to $\left.50 \mathrm{mg} W_{\text {total }}\right)$ of ascidjans were measured at different temperatures at intervals of up to $3^{\circ} \mathrm{C}$ every second day (salinity: 16 to $18 \%$ ). Initial algal cell concentrations were 3 to $6 \times 10^{3}$ cells $\mathrm{ml}^{-1}$ and additional Rhodomonas baltica cells were added about every 30 min until a constant filtration rate was obtained. In addition, an experiment on the effect of acute changes in temperature was performed on a group of 'small' ascidians ( $\mathrm{n}=5$; range: 48 to $66 \mathrm{mg} \boldsymbol{W}_{\text {total }}$ ) Filtration rate was measured within 2 h after a rise or fall in temperature and until it reached a constant level.

Prior to the temperature-effect experiments, one of the 4 individual ascidians, and the group of ascidians used for the 'acute temperature change' experiment, had been acclimated for at least 4 wk at $15^{\circ} \mathrm{C}$, while the remaining ones had been collected in Kertinge Nor and acclimated at 4 to $5^{\circ} \mathrm{C}$.

Population study. Population density was estimated using photogrammetrical analysis of stereophotographs (Lundälv 1971). Several series of stereophotographs of $0.25 \mathrm{~m}^{2}$ bottom area each were taken along randomized transects at different times of the year (Nov 1990, Mar, May \& Sep 1991). The number of transects and stereophotographs in each transect varied between 1 transect of 15 photographs to 12 transects of 8 photographs. All transects were taken within the area where Ciona intestinalis occurs in Kertinge Nor. This area was determined by scuba diving along the borders of the population. In order to estimate mean dry weight of the population, a sample of more than 300 ascidians was randomly collected at the transects.

Dry weight was determined after drying at $95^{\circ} \mathrm{C}$ for ca $24 \mathrm{~h}$. Total dry weight ( $W_{\text {total }}$ ) was defined as the dry weight of a whole ascidian, while dry weight of organs ( $W_{\text {organ }}$ ) was the dry weight of the ascidian without the tunica.

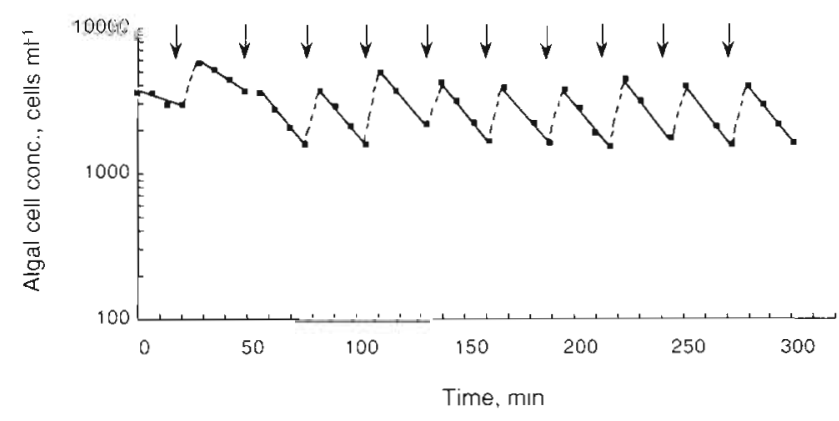

Fig. 2. Ciona intestinalis. Reduction in algal cell concentration due to grazing by a group of small ascidians ( $\mathrm{n}=10)$. Arrows indicate additions of algal suspension. The calculated filtration rates are shown in Fig. 4 (S, 5000)

\section{RESULTS}

\section{Filtration rate}

Fig. 2 shows the results of a typical filtration experiment with Ciona intestinalis. Reduction in algal cell concentration due to grazing of the ascidian was constant and high after an initial lag-phase of about $1 \mathrm{~h}$ with a lower filtration rate. The maximum filtration rate of $C$. intestinalis following the lag-phase [which equals filtration capacity $\left(F_{\max }, \mathrm{ml} \mathrm{min}^{-1}\right.$ ind $\left.\left.^{-1}\right)\right]$, expressed as a function of the total body size $\left(W_{\text {total }}\right)$ and organ dry weight $\left(W_{\text {organ }}\right.$ ) at particle concentrations between 3 and $10 \times 10^{3}$ cells $\mathrm{ml}^{-1}$, is shown in Fig. 3 .

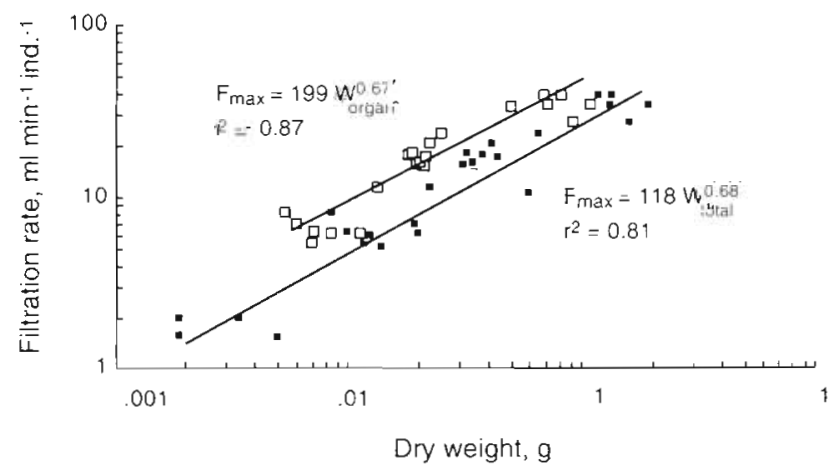

Fig. 3. Ciona intestinalis. Filtration rate $\left(F_{\max }\right)$ at $15^{\circ} \mathrm{C}$ as a function of $W_{\text {organ }}(0)$ and $W_{\text {tolsl }}(\mathbf{a})$. Regression lines and equations for the lines are shown on the figure 


\section{Algal cell concentration}

Filtration rate as a function of time and algal cell concentration is shown in Fig. 4. For both small and large ascidians filtration rates reached a constant, maximum level at low algal cell concentrations. At high algal cell concentrations, filtration gradually decreased after the maximum had been reached. Particle concentrations causing declining filtration in small ascidians were lower than for larger individuals. The reduced filtration rate in the group of small ascidians at $10^{4}$ cells $\mathrm{ml}^{-1}$ was probably caused by disturbance of the animals during addition of algal cells, and the reduced values were not used in the calculation of $F_{\max }$.
The duration of the initial lag-phase observed in starved ascidians was dependent on the algal cell concentration (Fig. 5). With increasing concentrations, duration of the lag-phase decreased to a minimum. The duration of the lag-phase was shorter for smaller ascidians.

The volume of algal cells that can be eaten before $F_{\text {max. }}$ is reduced may be regarded as a measure of the gut capacity (see Table 1). In small ascidians the gut capacity was approximately $1.3 \times 10^{9} \mu \mathrm{m}^{3}$, and when that was reached filtration rate decreased, as shown in the experiment with $15 \times 10^{3} \mathrm{cells} \mathrm{m}^{-1}$. At low algal concentrations gut capacity was not reached and filtration rate remained constant. At high algal concentrations the time required for filling the gut decreases with increasing algal concentration, leading to a shorter period with maximum filtration rate. The large ascidians had a higher gut capacity, resulting in decreased filtration rates only at cell concentrations above $2 \times 10^{4} \mathrm{cells} \mathrm{ml}^{-1}$. The reduced filtration rates at very high particulate concentrations resulted in constant ingestion rates (Fig. 6) as a function of algal cell concentration.

\section{Temperature effect}

As can be seen from Fig. 7, filtration rates varied linearly with temperature between 4 and $21^{\circ} \mathrm{C}$ (see also Table 2). Temperatures above ca $21^{\circ} \mathrm{C}$ caused a large decrease in filtration rate, irrespective of initial acclimation temperature. Ciona intestinalis responded within 2 to $4 \mathrm{~h}$ to changes in temperature, except at temperatures above $21^{\circ} \mathrm{C}$, when acclimation time was longer (Fig. 8).

\section{Population study}

The population of Ciona intestinalis in Kertinge Nor was limited to the central and northern part of the area. Within the area of distribution the population was very patchy, with ascidians in large clumps attached mainly to the eelgrass Zostera marina. Within one transect the density of animals could vary between zero and several hundred per $\mathrm{m}^{2}$, and there was no autocorrelation within the transects $(p>0.05)$.

Fig. 4. Ciona intestmalis. Filtration rate as a function of time at different algal cell concentrations in a group of small $(\mathrm{S}, \mathrm{n}=10)$ and a group of large $(\mathrm{L}$. $n=6$ ) ascidians. Initial algal cell concentration (cells $\mathrm{ml}^{-1}$ ) is given in each panel

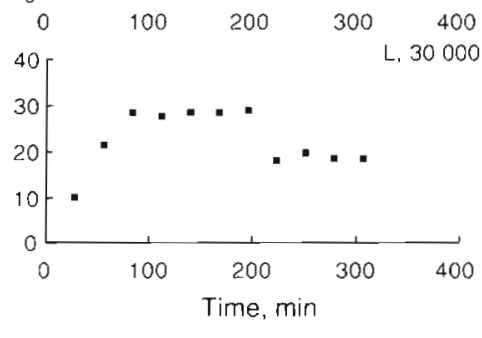




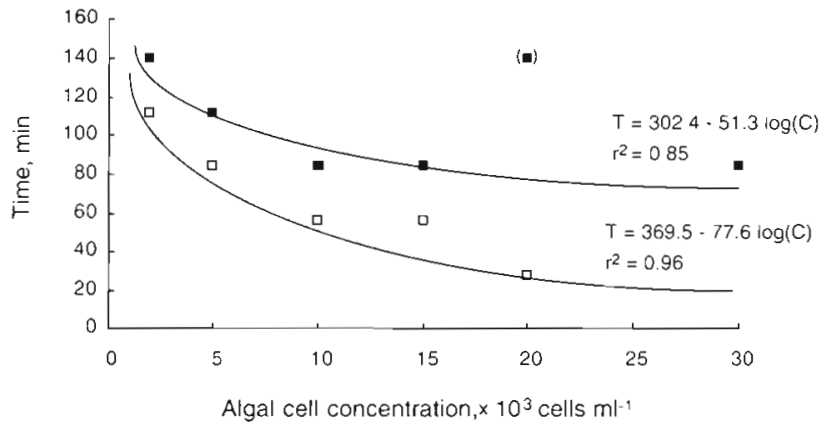

Fig. 5. Ciona intestinalis. Duration of initial lag-phase in a group of small ( $\square$ ) and a group of large ( $)$ ascidians. Lines are fitted by a logarithmic function and are shown on the figure together with the equations. The point in brackets was omitted in calculating the line

Table 1. Ciona intestinalis. Gut capacity, $\mathrm{T}_{\text {tot }}=F_{\max } \times \Delta t \times C \times$ vol, is calculated for a group of small $(n=10)$ and a group of large $(n=6)$ ascidians at different algal cell concentrations. $F_{\max }$ is maximum filtration rate at a given concentration $\left|C=\left(C_{2}-C_{1}\right) / \ln \left(C_{2} / C_{1}\right)\right|, \Delta t$ is time of maximum filtration and $\mathrm{vol}$ is the mean volume of an algal cell $\left(129.9 \pm 8.2 \mu \mathrm{m}^{3}\right)$. Gut capacity is calculated only for algal concentrations at or above incipient limiting concentration

\begin{tabular}{|c|c|c|c|c|}
\hline $\begin{array}{l}\text { Feeding } \\
\text { level }\end{array}$ & $\begin{array}{c}F_{\max } \\
\left(\mathrm{ml} \mathrm{min} \mathrm{mind}^{-1}{ }^{-1}\right)\end{array}$ & $\begin{array}{c}\Delta t \\
(\mathrm{~min})\end{array}$ & $\begin{array}{c}C \\
\text { (cells } \mathrm{ml}^{-1} \text { ) }\end{array}$ & $\begin{array}{c}T_{\text {tot }} \\
\left(\mu \mathrm{m}^{3}\right)\end{array}$ \\
\hline \multicolumn{5}{|c|}{ Small ascidians } \\
\hline 10000 & 5.65 & 224 & 7690 & $1.26 \times 10^{9}$ \\
\hline 15000 & 5.13 & 140 & 13200 & $1.23 \times 10^{9}$ \\
\hline 20000 & 4.77 & 112 & 17600 & $1.23 \times 10^{9}$ \\
\hline \multicolumn{5}{|c|}{ Large ascidians } \\
\hline 15000 & 34.06 & 224 & 9500 & $9.41 \times 10^{9}$ \\
\hline 20000 & 31.35 & 168 & 14500 & $9.92 \times 10^{9}$ \\
\hline 30000 & 28.19 & 112 & 24800 & $1.02 \times 10^{10}$ \\
\hline
\end{tabular}

The number of ascidians in the stereophotographical quadrats fitted a logarithmic normal distribution when only quadrats with at least one animal were used, resulting in transects with identical variance $(p=0.81$; Bartlett's test). Using a 1-factor ANOVA on the ln-transformed data a significant dif-

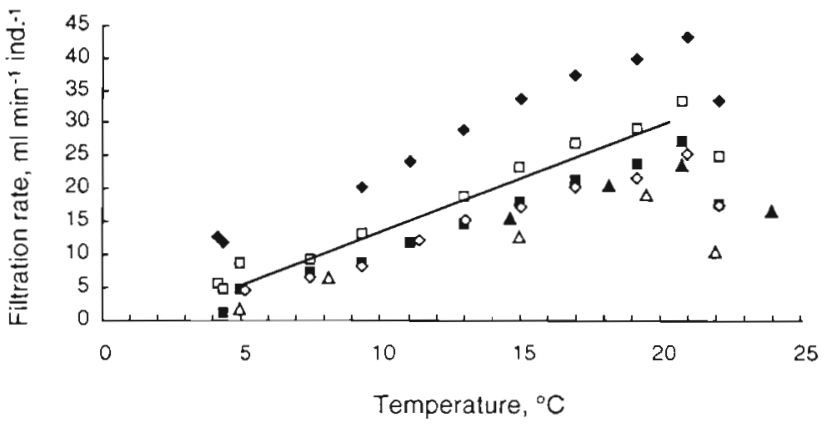

Fig. 7. Ciona intestinalis. Filtration rate $\left(F_{\max }\right)$ as a function of temperature. Regression parameters and symbols are explained in Table 2. Filtration rates at temperatures above $21^{\circ} \mathrm{C}$ are not included in the line

Table 2. Ciona intestinalis. Regression parameters for the relation between filtration rate $\left(F_{\max }, \mathrm{ml} \mathrm{min}^{-1}\right.$ ind. $\left.{ }^{-1}\right)$ and temperature $\left(T,{ }^{\circ} \mathrm{C}\right): F_{\max }=b T+a$. The line is a common description of all measurements and $\mathrm{n}$ is the number of points included in the regression line. Symbols represent measurements on individual ascidians except as otherwise noted

\begin{tabular}{|c|c|c|c|c|c|}
\hline & a & $b$ & $r^{2}$ & $\mathrm{n}$ & $T\left({ }^{\circ} \mathrm{C}\right)$ \\
\hline$\Delta^{\circ}$ & -3.05 & 1.11 & 0.99 & 4 & $5-19$ \\
\hline$\triangle$ & -4.02 & 1.33 & 0.99 & 3 & $15-20$ \\
\hline 0. & -3.07 & 1.33 & 0.99 & 9 & $5-21$ \\
\hline 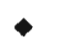 & 3.73 & 1.89 & 0.99 & 9 & $4-21$ \\
\hline - & -1.56 & 1.63 & 0.99 & 10 & $4-21$ \\
\hline$\square$ & -4.38 & 1.49 & 0.99 & 10 & $4-21$ \\
\hline Line & -1.21 & 1.46 & 0.66 & 45 & $4-21$ \\
\hline
\end{tabular}

ference between seasons $(p<0.0001)$ was found. The ln-transformed geometric means were recalculated into mean number of ascidians per stereophotographic quadrat according to Cohen (1991). Finally the mean was corrected for the number of quadrats with no ascidians by multiplying with the factor $K=$ $n^{\prime} / n$, where $n^{\prime}$ is the number of quadrats with at least 1 ascidian and $n$ is the total number of quadrats for
Fig. 6. Ciona intestinalis. Mean ingestion rate at different algal cell concentrations in a group of small ( $\mathrm{n}=10)$ and a group of large $(n=6)$ ascidians, based on data in Fig. 4
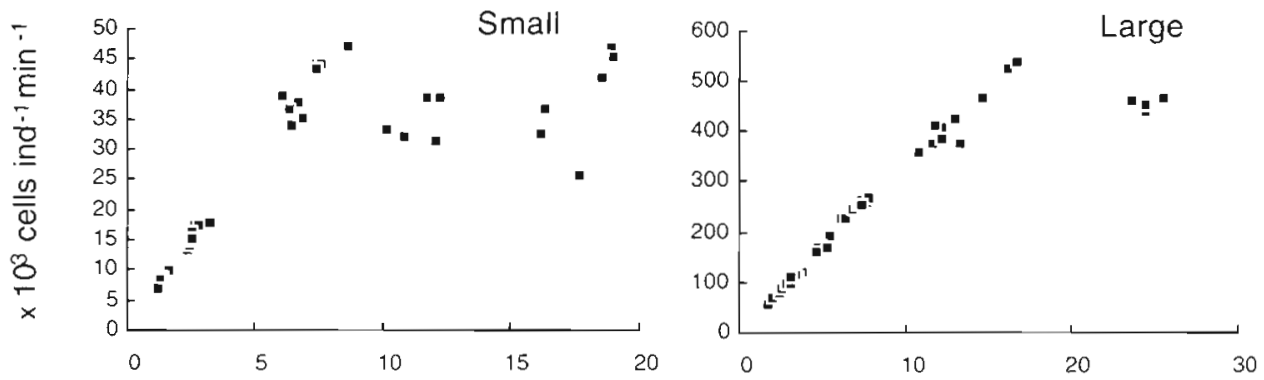

Algal cell concentration, $\times 10^{3}$ cells $\mathrm{mr}^{1}$ 


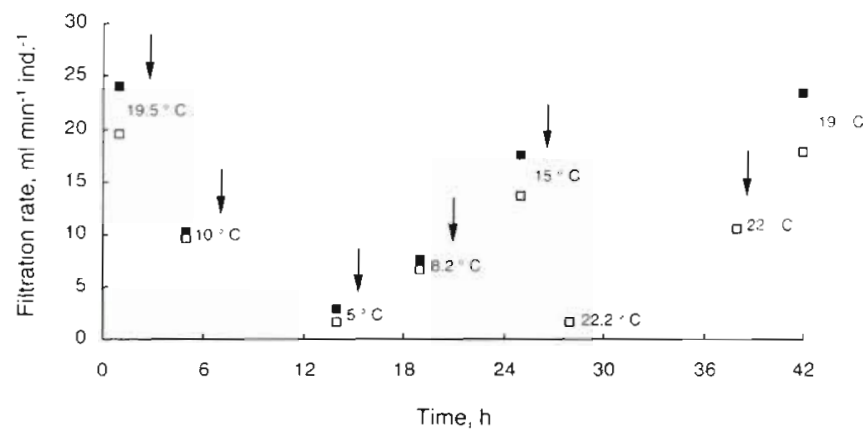

Fig. 8. Ciona intestinalis. Effects of acute changes in temperature $\left(T,{ }^{\circ} \mathrm{C}\right)$ on filtration rate as a function of time. The points are constant filtration rate after acute change in temperature (ㄷ) and filtration rate calculated as $F=118 W_{\text {tota! }}^{0.68}+$ $1.46(T-15)(-)$ at the temperatures shown on the figure and using $W=59 \mathrm{mg}$. Arrows indicate changes in temperature

Table 3. Ciona intestinalis. Population data from Kertinge Nor. $n$ is the total number of stereophotographical quadrats, $n^{\prime}$ is the number of quadrats with at least 1 individual, $a$ is the mean number of animals in $n^{\prime}$ quadrats, and $b$ is the estimated number of individuals per $\mathrm{m}^{2} 95 \%$ confidence limits are given in parentheses

\begin{tabular}{lcccc|}
\hline Month & $n$ & $n^{\prime}$ & \multicolumn{1}{c}{$a$} & $b$ \\
\hline Nov 1990 & 16 & 14 & $77(40-148)$ & $270(140-518)$ \\
Mar 1991 & 48 & 25 & $25(16-41)$ & $52(33-85)$ \\
May 1991 & 52 & 18 & $11(6-19)$ & $15(8-26)$ \\
Sep 1991 & 96 & 89 & $45(38-55)$ & $167(141-204)$ \\
\hline
\end{tabular}

each season. The data are summarized in Table 3. A more detailed description of the population ecology of C. intestinalis in Kertinge Nor will be presented elsewhere (Petersen \& Svane unpubl.).

Table 4 shows estimates of total population filtration. It is seen that estimated population filtration varies considerably during the year. In September the population can clear a volume of water corresponding to the total volume of the cove per day, while in May it can only clear 0.11 times the total volume per day. To illustrate the impact of the total population filtration on the planktonic community, the mean residence time $\left(t_{1 / 2}\right)$ for algal cells in a fully mixed water column $\left(2 \mathrm{~m}^{3}\right)$ above the $C$. intestinalis population varies between 9 and $70 \mathrm{~h}$, depending on time of year.

The filtration capacity of the Ciona intestinalis population in Kertinge Nor varies during the year as a result of variation in population density and individual temperature-dependent filtration rates. Thus, population filtration capacity is low in winter due to low temperatures and in mid-summer when the old generation has virtually died off and population biomass is low, but high in late summer and early fall when biomass is high and temperatures relatively high.

\section{DISCUSSION}

In late summer Ciona intestinalis is potentially a key organism in the control of phytoplankton in the Kertinge Nor ecosystem. At this time the population has a theoretical capacity to clear a volume of water corresponding to the total volume of the cove per day (Table 4). If the water column is appropriately mixed the $C$. intestinalis population can strongly influence or control the phytoplankton community because the mean residence time for algal cells may be less than $1 \mathrm{~d}$, i.e. shorter than the normal generation time for algal cells. It is unlikely that total mixing prevails, but given the shallowness of the cove and the position of the ascidians mainly on a semi-stationary substrate reaching up into the water column, it is possible that the $C$. intestinalis population actually did control the phytoplankton community in Kertinge Nor during the late summer of 1991. This seems to be confirmed by very low chlorophyll a values of about $2.5 \mu \mathrm{g} \mathrm{I}^{-1}$ measured by the county of Fyn in the same period (Fyns Amt 1992) In contrast, the significance of C. in-

Table 4. Ciona intestinalis. Population filtration in Kertinge Nor. Total dry weight ( $\left.W_{\text {total }}\right)$ is given as mean \pm SE. Total population filtration in Kertinge Nor is computed using an estimated area of $2.81 \mathrm{~km}^{2}$ covered with C. intestinalis and data from Table 3 . $Q$ is the quotient of the filtration potential of the $C$. intestinalis population to the water volume of Kertinge Nor, which was calculated based on a total area of $5.48 \mathrm{~km}^{2}$ and an average depth of $2 \mathrm{~m}$. The theoretical mean residence time $\left(t_{1 / 2}\right)$ was calculated as: $t_{1 / 2}=(V / F) \times \ln 2$ (where $V=$ water-volume and $F=$ filtration rate), using an average depth of $2 \mathrm{~m}$. Filtration rate was calculated as $F=118 W_{\text {toral }}^{0.68}+1.46(T-15)$, where $T=$ temperature $\left({ }^{\circ} \mathrm{C}\right)$

\begin{tabular}{|c|c|c|c|c|c|c|}
\hline \multirow[t]{2}{*}{ Month } & \multirow{2}{*}{$\begin{array}{c}\mathrm{W}_{\text {total }} \\
\text { (mg ind. }{ }^{-1} \text { ) }\end{array}$} & \multirow{2}{*}{$\begin{array}{c}F \\
\left(1 \mathrm{~h}^{-1} \text { ind }^{-1}\right)\end{array}$} & \multicolumn{2}{|c|}{ Population $F$} & \multirow{2}{*}{$\begin{array}{c}Q \\
\left(d^{-1}\right)\end{array}$} & \multirow{2}{*}{$\begin{array}{l}t_{1 / 2} \\
(\mathrm{~h})\end{array}$} \\
\hline & & & $\left(1 \mathrm{~h}^{-1} \mathrm{~m}^{-2}\right)$ & $\left(m^{3} h^{-1}\right)$ & & \\
\hline Nov 1990 & $85.8 \pm 2.7$ & 0.47 & 126.9 & $3.6 \times 10^{5}$ & 0.79 & 10.9 \\
\hline Mar 1991 & $56.6 \pm 2.2$ & 0.40 & 21.0 & $5.9 \times 10^{4}$ & 0.13 & 66.0 \\
\hline May 1991 & $168.8 \pm 9.5$ & 1.24 & 18.6 & $5.2 \times 10^{4}$ & 0.11 & 74.5 \\
\hline Sep 1991 & $55.5 \pm 2.0$ & 0.99 & 165.3 & $4.6 \times 10^{5}$ & 1.00 & 8.4 \\
\hline
\end{tabular}


testinalis is limited during early spring and midsummer. However, the low population filtration during summer is somewhat underestimated in Table 4, since filtering ascidians below 5 to $10 \mathrm{~mm}$ in size were not included in the calculations.

The maximal filtration rates measured in this study are 1.5 to 3 times higher than previously reported rates (Jørgensen 1949, Fiala-Médioni 1974, 1978b, Randløv \& Riisgård 1979, Robbins 1983). There may be several reasons for the discrepancies between the different measurements. Ciona intestinalis is, like many bivalves (Møhlenberg \& Riisgård 1979), very sensitive to chemical and mechanical disturbance. Disturbance causes the ascidians to close their siphons and thereby stop filtration. Even after opening of the siphons, filtration rates remain low or zero for some time. It is impossible to judge, based on its appearance, whether or not C. intestinalis is pumping at maximum rate, unlike for mussels in which the closure of the valve gap indicates the degree of water transport (Riisgård \& Møhlenberg 1979). When acclimating the ascidians in closed containers after mechanical disturbance, subsequent measurements of filtration rates may result in low etimates. If the ascidians are in the initial lag-phase (Fig. 4) this may result in lower rates as reported by Randløv \& Riisgård (1979), who did not notice the lag-phase phenomenon.

Some techniques used to measure filtration rates tend to underestimate the true rate of water transport (Riisgård \& Møhlenberg 1979) and may be the explanation (Randløv \& Riisgård 1979) for the lower filtration rates in ascidians found by Fiala-Médioni (1974, 1978b). Particle load has an effect on filtration rate. As seen from the experiments with different algal cell concentrations (Fig. 4) and previous reports (Robbins 1983), filtration rate is not only reduced in ascidians but also in 'overloaded' Ciona intestinalis exposed to high concentrations of particulate matter. A very high concentration of algal cells $\left(2 \times 10^{4}\right.$ cells $\left.\mathrm{ml}^{-1}\right)$ may be an additional cause for the lower filtration rate found by Fiala-Médioni $(1974,1978 \mathrm{~b})$. This is further supported by the initial decline in filtration rate found in her $24 \mathrm{~h}$ experiment at an algal cell concentration of

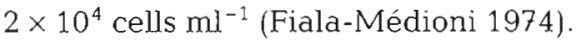

The exponent $b$ in the allometric equation $F_{\max }=$ a $W^{b}$ is the same whether organ dry weight or total dry weight is used, indicating isometric growth of test and organs in Ciona intestinalis from Kertinge Nor (Fig. 3). An exponent of 0.67 is in good agreement with other findings (Randløv \& Riisgård 1979, Robbins 1983).

The present investigation shows that particle loads above a certain level result in a decrease in Ciona intestinalis filtration rate, the level being dependent on the ascidians size (Fig. 5). This is in agreement with
Winter (1978), Navarro \& Winter (1982), Robbins (1983), Sprung \& Rose (1988) and Riisgård (1991). According to Robbins $(1983,1984)$ ascidians do not discriminate between inorganic and organic particles, since gut contents mirror suspension composition, and thus evince a similar 'functional response', i.e. constant ingestion rate at high algal cell concentrations, when subjected to suspensions of either organic or inorganic particles. There has been some debate about the nature of this functional response. In Table 1 it is seen that filtration rate decreased when a threshold volume of algal cells had been ingested (defined as 'gut capacity' in this work), dependent on the size of the ascidian. According to Millar (1953), the approximate volume of the gut of an ascidian about $90 \mathrm{~mm}$ long can be estimated as 9 to $16 \mathrm{~mm}^{3}$. This corresponds well the threshold volume for algal cells of $10 \mathrm{~mm}^{3}$ found in the group of large ascidians, which are 76 to $102 \mathrm{~mm}$ long. The declining filtration rate with increasing, high concentrations of algal suspension may thus be a protective reaction against overloading of the feeding system (Riisgård \& Møhlenberg 1979, Riisgård 1991).

A decrease in filtration rate as a response to environmental factors could occur either though direct nervous control of the ciliary pump, resulting in reduced pumping rates, or indirectly by an increased rate of spontaneous squirting (Hoyle 1953) since the mucus net does not seem to become more leaky (Randløv \& Riisgård 1979, Robbins 1984). Specimens of Ciona intestinalis exposed to high algal cell concentrations in the present experiments showed increasing rates of squirting as also observed by Robbins (1984). There is no doubt that during squirting and the subsequent opening of the siphons there is little or no water pumping. This will reduce the mean filtration rate measured over a given period of time. Squirting, however, does not only occur at high particulate concentrations, but is also a response to single large particles or chemical stimuli (Day 1919, Hoyle 1953, Werner \& Werner 1954), and thus does not seem to explain the decreasing filtration rate in Fig. 4 adequately. This suggests that $C$. intestinalis is able to reduce its filtration rate at high algal cell concentrations by other means, such as reduced pumping rate or reduced retention efficiency of the mucus net. A decreased pumping rate at high particulate concentrations has been observed by Robbins (1984) in Ascidia mentula.

The present work shows that at high algal cell concentrations (>15000 Rhodomonas baltica cells $\mathrm{ml}^{-1}$; Fig. 4) reduction in filtration rate may be triggered when the gut capacity has been reached. The rise in filtration rate when algae are added to starved Ciona intestinalis (Figs. $2 \& 4$ ) in filtered seawater is probably 
a result of chemical stimuli, since the duration of the initial period of low filtration rate is dependent on algal cell concentration. The mechanism that controls the pumping rate in this case is unknown, but it may be increased ciliary activity (more beating cilia) and/or increased beating frequency of the water-pumping cilia.

The positive relationship between filtration rate and temperature in Ciona intestinalis (Fig. 7), up to a certain level, is in agreement with findings for other ascidians (Holmes 1973, Fiala-Médioni 1978c, Robbins 1983) and mussels (Winter 1978, Jørgensen et al. 1990). The rapid and linear response in filtration rate to changes in temperature in the range 5 to $20^{\circ} \mathrm{C}$ is contradictory to the concept of a temperature optimum (Winter 1978, Brock \& Kofoed 1987) and temperature acclimation (Widdows \& Bayne 1971) reported for some mussels, but seems to be very similar to the temperature pumping-rate relationships described for Mytilus edulis (Jørgensen et al. 1990) and Sabella penicillus (Riisgård \& Ivarsson 1990). The models described for these 2 species, however, do not adequately describe the temperature-dependent changes in filtration rates found in $C$. intestinalis. While the increase in filtration rate is 5 - to 7 -fold in $C$. intestinalis it is only about 2 fold in $S$. penicillus and $M$. edulis over a temperature range of 5 to $20^{\circ} \mathrm{C}$. The larger increase in filtration in $C$. intestinalis suggests a substantial effect of increased ciliary activity with temperature, in contrast to $M$. edulis and $S$. penicillus, where the variation in pumping rate apparently could be explained solely by the temperature-dependent viscosity.

The ascidian ciliary pump has a maximum pressure rise of about $1.2 \mathrm{~mm} \mathrm{H}_{2} \mathrm{O}$ and a normal operating point of about $0.3 \mathrm{~mm} \mathrm{H}_{2} \mathrm{O}$ (Riisgård 1988). The ascidian pump is weak compared to the ciliary gill pump of Mytilus edulis, which has a maximum pressure rise of about $3.5 \mathrm{~mm} \mathrm{H}_{2} \mathrm{O}$ and a normal operating point of $1.0 \mathrm{~mm} \mathrm{H}_{2} \mathrm{O}$ (Jørgensen et al. 1986, 1988). A decrease in temperature will also lead to increased pump system resistance (more friction due to higher viscosity), and the weak ascidian pump is therefore likely to be more sensitive to temperature than the stronger mussel pump. In the Sabella penicillus compound ciliary pump the normal operating point is very low $0.02 \mathrm{~mm} \mathrm{H}_{2} \mathrm{O}$; Riisgård \& Ivarsson 1990) due to a neglible system resistance, and a decrease in filtration rate with decreasing temperature may thus reflect a fairly pure effect of decreased ciliary beat frequency. This may be influenced by the lower water viscosity as well as by reduced biological activity. From the above considerations it is clear that there is no simple and common relationship which allows predictions to be made regarding the temperature effect on filtration rate in ciliary suspension feeders.
Acknowledgements. Thanks are due to Dr I. Svane for loan of equipment, assistance in diving, fruitful discussions and critically reading the manuscript, to $D r V$. Forbes for improvements in the style of the manuscript and to $\mathrm{C}$. T Agger for help with the statistical treatments. The study was supported by a HAV-90 grant of the Danish National Agency of Environmental Protection.

\section{LITERATURE CITED}

Brock, V., Kofoed, L. H. (1987). Species specific irrigatory efficiency in Cardium (Cerastoderma) edule (L.) and C. lamarcki (Reeve) responding to different environmental eemperatures. Biol. Oceanogr. 4: 211-226

Cohen, A. C. (1991). Truncated and censored samples. Marcel Dekker, New York

Day, E. C. (1919). The physiology of the nervous system of the tunicate. J. exp. Zool. 28: 307-335

Dybern, B. I. (1963). Biotope choice in Ciona intestinalis (L.). Influence of light. Zool. Bidr. Upps. 35: 589-602

Dybern, B. I. (1965). The life cycle of Ciona intestinalis (L.) f. typica in relation to the environmental temperature. Oikos 16: 109-131

Fiala-Médioni, A. (1974). Ethologie alimentaire d'invertébrés benthiques filtreurs (ascidies). II. Variations des taux de filtration et de digestion en fonction de l'espèce. Mar. Biol. 28: $199-206$

Fiala-Médioni, A. (1978a). Filter-feeding ethology of benthic invertebrates (Ascidians). III. Recording of water current in situ - rate and rhythm of pumping. Mar. Biol. 45: $185-190$

Fiala-Médioni, A. (1978b). Filter-feeding ethology of benthic invertebrates (Ascidians). IV. Pumping rate, filtration rate, filtration efficiency. Mar. Biol. 48: 243-249

Fiala-Médioni, A. (1978c). Filter-feeding ethology of benthic invertebrates (Ascidians). V. Influence of temperature on pumping, filtration and digestion rates and rhythms in Phallusia mammillata. Mar. Biol. 48: 251-259

Fiala-Médioni, A. (1979). Influence de la concentration algala du milieu sur le pompage, la filtration et l'absorption de Phallusia mammillata (Cuvier, 1815) (ascidie simple). Annls. Inst. océanogr. (Paris) 55: 155-162

Fyns Amt (1992). Vandmiljøovervågning - Kystvande 1991 Fyns Amt, Teknik- og Miljøforvaltningen, Odense

Holmes, N. (1973). Water transport in the ascidians Styela clava Herdman and Ascidiella aspersa (Müller). J. exp. mar. Biol. Ecol. 11: 1-13

Hoyle, G. (1953). Spontaneous squirting of an ascidian, Phallusia mammillata Cuvier. J. mar. biol. Ass. U.K. 31 : 541-562

Jørgensen, C. B. (1949). Feeding-rates of sponges, lamellibranchs and ascidians. Nature 163: 912

Jørgensen, C. B., Famme, P., Kristensen, H. S., Larsen, P. S., Møhlenberg, F., Riisgård, H. U. (1986). The bivalve pump. Mar. Ecol. Prog. Ser. 34: 69-77

Jørgensen, C. B., Kiørboe, T., Møhlenberg, F., Riisgård, H. U. (1984). Ciliary and mucus-net filter feeding, with special reference to fluid mechanical characteristics. Mar. Ecol. Prog. Ser. 15: 283-292

Jørgensen, C. B., Larsen, P. S., Møhlenberg, F., Riisgård, H. U. (1988). The mussel pump: properties and modelling. Mar Ecol. Prog. Ser. 45: 205-216

Jørgensen, C. B., Larsen, P. S., Riisgård, H. U. (1990). Effects of temperature on the mussel pump. Mar. Ecol. Prog. Ser $64: 89-97$ 
Lundälv, T (1971). Quantitative studies on rocky-bottom biocoenoses by underwater photogrammetry. A methodological study. Thalassia jugosl. 7: 201-208

Millar, R. H. (1953). Ciona. The University Press, Liverpool

Millar, R. H. (1971). The biology of ascidians. Adv. mar. Biol. 9: $1-100$

Møhlenberg, F., Riisgård, H. U. (1979). Filtration rate, using a new indirect technique, in thirteen species of suspensionfeeding bivalves. Mar. Biol. 54: 143-147

Navarro, J. M. \& Winter, J. E. (1982). Ingestion rate, assimilation efficiency and energy balance in Mytilus chilensis in relation to body size and different algal concentrations. Mar. Biol. 67: 255-266

Randløv, A., Riisgård, H. U. (1979). Efficiency of particle retention and filtration rate in four species of ascidians. Mar. Ecol. Prog. Ser 1: 55-59

Riisgård, H. U. (1988). The ascidian pump: properties and energy cost. Mar. Ecol. Prog. Ser. 47: 129-134

Riisgård, H. U. (1991). Filtration rate and growth in the blue mussel, Mytilus edulis Linneaus: dependence on algal concentration. J. Shellfish Res. 10: 29-35

Riisgård, H. U., Ivarsson, N. M. (1990). The crown-filament pump of the suspension-feeding polychaete Sabella penicillus: filtration, effects of temperature, and energy cost. Mar. Ecol. Prog. Ser. 62: 249-257

Riisgård, H. U., Mohlenberg, F. (1979). An improved automatic recording apparatus for determining the filtration

This article was submitted to the editor rate of Mytilus edulis as a function of size and algal concentration. Mar. Biol. 52: 61-67

Robbins, I. J. (1983). The effects of body size, temperature, and suspension density on the filtration and ingestion of inorganic particulate suspensions by ascidians. J. exp. mar. Biol. Ecol. 70: 65-78

Robbins, I. J. (1984). The regulation of ingestion rate, at high suspended particulate concentrations, by some phleobranchiate ascidians. J. exp. mar Biol. Ecol. 82: $1-10$

Sprung, M., Rose, U. (1988). Influence of food size and food quantity on the feeding of the mussel Dreissena polymorpha. Oecologia 77: 526-532

Werner, E., Werner, B. (1954). Über den Mechanismus des Nahrungserwerbs der Tunicaten, speziell der Ascidien. Helgoländer wiss. Meeresunters. 5: 57-92

Widdows, J., Bayne, B. L. (1971). Temperature acclimation of Mytilus edulis with reference to its energy budget. J. mar. biol. Ass. U.K. 51: $827-843$

Winter, J. E. (1973). The filtration rate of Mytilus edulis and its dependence on algal concentration, measured by a continuous automatic recording apparatus. Mar. Biol. 22: $317-328$

Winter, J. E. (1978). A review on the knowledge of suspension-feeding in lamellibranciate bivalves, with special reference to artificial aquaculture systems. Aquaculture 13: $1-33$

Manuscript first received: March 30, 1992

Revised version accepted: September 14, 1992 


\section{Erratum}

Re: J. K. Petersen, H. U. Riisgård

Mar. Ecol. Prog. Ser. 88: 9-17 (1992)

- On page 14, Fig. 8 caption, line 4 : read $F=(8.3 T-6.9) W_{\text {total }}{ }^{0.68}$. The figure is correct.

- On page 14, Table 3. Additional data give new values:

\begin{tabular}{lcccc|}
\hline Month & $n$ & $n^{\prime}$ & $a$ & $b$ \\
\hline Nov 1990 & 16 & 14 & $129(62-269)$ & $450(215-940)$ \\
Mar 1991 & 34 & 26 & $25(15-42)$ & $76(45-129)$ \\
May 1991 & 43 & 26 & $8(5-13)$ & $20(13-31)$ \\
Sep 1991 & 96 & 89 & $64(53-77)$ & $237(195-287)$ \\
\hline
\end{tabular}

- On page 14, Table 4 caption, line 6: read $F=(8.3 T-6.9) W_{\text {total }}^{0.68}$. New Table 4 is:

\begin{tabular}{|c|c|c|c|c|c|c|}
\hline \multirow[t]{2}{*}{ Month } & \multirow{2}{*}{$\begin{array}{c}W_{\text {total }} \\
\text { (mg ind } .^{-1} \text { ) }\end{array}$} & \multirow{2}{*}{$\begin{array}{c}F \\
\left(\mathrm{l} \mathrm{h}^{-1} \text { ind }^{-1}\right)\end{array}$} & \multicolumn{2}{|c|}{ Population $F$} & \multirow{2}{*}{$\begin{array}{c}Q \\
\left(\mathrm{~d}^{-1}\right)\end{array}$} & \multirow{2}{*}{$\begin{array}{l}t_{1 / 2} \\
\text { (h) }\end{array}$} \\
\hline & & & $\left(1 \mathrm{~h}^{-1} \mathrm{~m}^{-2}\right)$ & $\left(\mathrm{m}^{3} \mathrm{~h}^{-1}\right)$ & & \\
\hline Nov 1990 & $85.8 \pm 2.7$ & 0.39 & 175.9 & $4.9 \times 10^{5}$ & 1.07 & 7.9 \\
\hline Mar 1991 & $56.6 \pm 2.2$ & 0.39 & 29.9 & $8.4 \times 10^{4}$ & 0.18 & 46.4 \\
\hline May 1991 & $168.8 \pm 9.5$ & 1.88 & 37.6 & $1.1 \times 10^{5}$ & 0.24 & 36.8 \\
\hline Sep 1991 & $55.5 \pm 2.0$ & 0.81 & 191.2 & $5.4 \times 10^{5}$ & 1.18 & 7.3 \\
\hline
\end{tabular}

